\title{
Espejo y especularidad en As de oros de Rubén Bonifaz Nuño
}

\author{
Romuald-Achille Mahop Ma Mahop \\ (FALSH - Université de Yaoundé I) \\ mahorom2006@yahoo.fr
}

\section{RESUM}

El motiu del mirall figura entre els més freqüents del sistema simbòlic de la literatura moderna. Això s'aprecia especialment en l'obra lírica de diversos autors contemporanis on revesteix els més diversos matisos. El present article examina la reiteració de la imatgeria del mirall a As de oros (1981) del mexicà Rubén Bonifaz Nuño (1923-2013). El mirall s'estudia des de tres principals perspectives: la malenconia davant la degradació de l'aparença física, el desdoblament com a joc especular amb la identitat i, finalment, la postulació d'un temps inalterable de l'altre costat del mirall com a baluard contra l'esdevenir.

Paraules Clau

Rubén Bonifaz Nuño, poesia mexicana, motiu del mirall, melangia, vellesa.

\section{Resumen}

El motivo del espejo figura entre los más frecuentes del sistema simbólico de la literatura moderna. Esto se aprecia especialmente en la obra lírica de varios autores contemporáneos donde reviste los más diversos matices. El presente artículo examina la reiteración de la imaginería del espejo en $A s$ de oros (1981) del mexicano Rubén Bonifaz Nuño (1923-2013). El espejo se estudia desde tres principales perspectivas: la melancolía ante la degradación de la apariencia física, el desdoblamiento como juego especular con la identidad y, por último, la postulación de un tiempo inalterable del otro lado del cristal como baluarte contra el devenir.

Palabras Clave

Rubén Bonifaz Nuño, poesía mexicana, motivo del espejo, melancolía, vejez.

\section{RÉSUMÉ}

Le motif du miroir est parmi les plus fréquents du système symbolique de la littérature moderne. Ceci est particulièrement apprécié dans le travail lyrique de plusieurs auteurs contemporains où il a les nuances les plus diverses. Cet article examine la réitération de l'imagerie miroir dans As de Oros (1981) par le Mexicain Rubén Bonifaz Nuño (1923-2013). Le miroir est étudié à partir de trois perspectives principales: la mélancolie avant la dégradation de l'apparence physique, la scission comme un jeu spéculaire avec l'identité et, enfin, la postulation d'un temps inaltérable de l'autre côté du verre comme rempart contre le devenir.

MOTS CLÉ

Rubén Bonifaz Nuño, poésie mexicaine, raison du miroir, mélancolie, vieillesse. 


\begin{abstract}
The mirror has become one of the most common motives in the symbolical system of modern literature. Various contemporary poets show a predilection for this motif by using it in their works to depict several ideas. This essay studies the iterative mirror imagery in As de oros (1981), a collection of poems by the Mexican Rubén Bonifaz Nuño (1923-2013). The frequency of the mirror is analyzed here from three main perspectives: the melancholia due to physical decay, the theme of doubleness which problematizes specular identity and, finally, the postulation of an unalterable time which lives through the looking glass as a fortress against time's corruption.
\end{abstract}

\title{
KEY WORDS
}

Rubén Bonifaz Nuño, Mexican poetry, motif of the mirror, melancholia, old age.

\section{Introducción}

\author{
Nos acecha el cristal. Si entre las cuatro \\ paredes de la alcoba hay un espejo, \\ ya no estoy solo. Hay otro. Hay el reflejo \\ que arma en el alba un sigiloso teatro. \\ (Jorge Luis Borges, Los espejos) \\ Los espejos están llenos de gente. \\ Los invisibles nos ven. \\ Los olvidados nos recuerdan. \\ Cuando nos vemos, los vemos. \\ Cuando nos vamos, ¿se van? \\ (Eduardo Galeano, Espejos)
}

El motivo del espejo es uno de los más productivos en literatura, probablemente porque suele abrir camino a varias posibilidades de interpretación, por su capacidad de establecer puentes entre el plano real y el imaginario, sin olvidar sus conexiones con disciplinas como la psicología e incluso sus valores místicos y esotéricos. ${ }^{1}$ A lo largo de la historia de la literatura, el espejo ha ido ensanchando su horizonte simbólico, adquiriendo en ocasiones valores insospechados como los que ofrecen muchas composiciones poéticas de vanguardia ${ }^{2}$. En su empleo literario más corriente, el espejo suele abrir camino a una reflexión sobre la apariencia física. Asimismo, el espejo constituye un emblema perfecto para la construcción de una realidad en la que ficción

1. En su Dictionnaires des symboles, Jean Chevalier y Alain Gheerbrant mencionan, por ejemplo, el simbolismo del espejo en determinadas religiones orientales donde es un instrumento de conocimiento a través de la revelación de la verdad (tradición japonesa y búdica), o su empleo en diferentes formas del chamanismo (1990: 636).

2. Acordémonos, por ejemplo de aquel extraño "espejo, corriente por las noches", que "se hace arroyo y se aleja de mi cuarto”, según se lee en el poema epónimo del Espejo de agua de Vicente Huidobro (2011: 14). 
y enigma andan de la mano, como se aprecia en los dos epígrafes que abren este artículo. El simbolismo del espejo se expande a través de los siglos, proceso que culmina durante el siglo XX. Este ensayo se propone indagar la recurrencia del motivo del espejo en varias composiciones del poemario As de oros (1981) del mexicano Rubén Bonifaz Nuño (1923-2013). Este aspecto de la obra del poeta veracruzano no ha merecido todavía la debida atención crítica. Antes de abordar el cometido principal de este trabajo, quisiera comenzar por rastrear muy de paso, a modo de entrada en materia, el interés que otros clásicos hispánicos contemporáneos han mostrado por el motivo del espejo.

La frecuencia con la que los poetas recurren al espejo en sus composiciones hace de éste uno de los componentes fundamentales del repertorio simbólico de la poesía contemporánea. Está presente en la obra de varios clásicos de nuestro tiempo $\mathrm{y}^{3}$ una de las razones que explica esta predilección es la productividad del motivo ${ }^{4}$. En la poesía de Rubén Bonifaz Nuño, el espejo es inseparable del tema de la memoria y de la reflexión existencial, aspectos que constituyen los pilares del quehacer poético del escritor veracruzano. Analizaré el empleo del espejo aquí principalmente desde el poemario $A s$ de oros publicado en 1981 e incluido en la recopilación Versos (1978-1994). ${ }^{5}$

El estudio establece, como anuncia su título, un distingo entre espejo y especularidad. Esta separación se explica por la diferencia observada entre las figuraciones del espejo estrictamente hablando y otros modos de recreación o sugerencia poética del proceso físico de la reflexión. En este segundo caso, prefiero hablar de especularidad, es decir, una reflexión que se consigue con medios alternativos a los espejos convencionales, recursos que iré señalando y describiendo en su debido lugar.

Este ensayo se construye en torno a tres principales apartados. En el primero, se analiza el espejo como instrumento de meditación sobre la degradación del cuerpo; en el segundo, se aborda el tema del doble especular que desarrolla una visión del cuerpo y de la memoria. El tercer apartado, por su parte, explora las posibles conexiones entre la imaginería del espejo y el problema metafísico del instante que asoma en algunos textos de Bonifaz Nuño. Veremos así en qué medida, al perennizar en cierto modo la juventud, el espejo instaura una frágil perpetuidad que se encuentra, por decirlo de algún modo, del otro lado del cristal.

3. El mexicano Xavier Villaurrutia, por ejemplo, sintetizó su obsesión por los espejos a través de un memorable desdoblamiento de la voz poética y de los elementos primordiales que encontramos en su composición "Nocturno en que nada se oye" de Nostalgia de la muerte. Ni siquiera falta el espejo en un poeta como César Vallejo, a priori tan alejado de "poéticas de brillantina” o "poéticas de vitrina”, según palabras de Enrique Ballon Aguirre (2015: XXVIII, XXX). Es imposible no mencionar a un poeta como Jorge Luis Borges, tan obsesionado por los espejos. En el escritor argentino, según se lee en El hacedor, la intuición del lado misterioso de los espejos se acompańa de una fobia ante esos objetos que, según él, son responsables de una "duplicación o multiplicación espectral de la realidad" (1974: 786), artefactos "insomnes y fatales" que no son sino "elementales / ejecutores de un antiguo pacto" (814).

4. El crítico y teórico Michael Riffaterre ha insistido, en efecto, sobre la productividad literaria del motivo del espejo. Para Riffaterre, el espejo permite fáciles equiparaciones al tiempo que se presta a interpretaciones de tipo moral. El espejo no sólo funciona como un emblema de verdad o de ilusión, sino que también permite variaciones infinitas sobre la reflexión como fenómeno físico o mental, la mayoría de las cuales tienen su origen en la analogía platónica entre el espíritu y el espejo (1983: 49).

5. Todas las citas de corpus proceden de este volumen que reúne el conjunto de la poesía de Bonifaz Nuño que va de Tres poemas de antes (1978) hasta Trovas del mar unido (1994). 


\section{Una "contemplación que lamenta"}

En El agua y los sueños, Gaston Bachelard subraya la ambigüedad y la complejidad del narcisismo que puede encerrar al mismo tiempo una "contemplación que lamenta", una "contemplación esperada", una "contemplación que consuela" o una "contemplación que ataca" (2003: 39). La "contemplación que lamenta" remite a una actitud dolorosa ante las transformaciones que el devenir impone al cuerpo y que el cristal se encarga de revelarle al sujeto. Estudiaré este "narcisismo que lamenta" desde dos perspectivas: la actitud ante el cuerpo y lo que podríamos llamar memoria del espejo. La crítica de Rubén Bonifaz Nuño suele coincidir a la hora de trazar las líneas cardinales de su quehacer poético. Así, Carlos Montemayor señala tres principales caminos de acceso a la poesía de Rubén Bonifaz Nuño. El primero es el enfrentamiento del poeta con la fuerza corrosiva del tiempo, en un "vértigo en que los ańos parecen días consumiéndose como una fruta mordida". El segundo camino lo constituye el lenguaje, no un simple lujo sino una combativa "orfebrería verbal" mediante la cual el poeta arremete contra la soledad. El tercer camino se nutre de los precedentes y se construye a partir de saberes herméticos como la vieja cábala hebrea y la alquimia (2008: 4-5). Sandro Cohen, por su parte, piensa que el "triángulo poético" del escritor veracruzano lo constituyen "la búsqueda formal, la búsqueda amorosa y la del sentido del ser humano dentro de las civilizaciones que ha construido" (2008: 106). La línea existencial de esta escritura parece acentuarse a lo largo de la madurez del poeta, lo cual, según ciertos críticos, sirve de línea estética divisoria entre la colección De otro modo lo mismo (1979) y el volumen Versos (1978-1994). ${ }^{6}$ Incluso se ha leído la poesía de Rubén Bonifaz Nuño como una expresión de la absorción de saberes esotéricos, especialmente la alquimia y la filosofía hermética ${ }^{7}$.

Asocio el espejo y lo especular con la reflexión existencial del autor porque tales figuraciones ponen de manifiesto el enfrentamiento del sujeto lírico con el demoledor flujo temporal, inquietud rastreable a lo largo de la obra del poeta veracruzano. Esta relación entre el espejo y la condición humana también ha sido establecida por Carlos Gómez Carro cuando advierte en la obra de Bonifaz Nuńo la presencia de "ojos que nos arman con el valor de mirar en el espejo nuestra diaria desventura". Al mirarse, prosigue Gómez Carro, el ser encara "la irremediable visión de nuestro lento despeñar en el abismo de la existencia” (2007: 2). La crítica ha reconocido la complejidad de las fuentes que enriquecen la poética de $A s$ de oros, una característica susceptible de desanimar a más de un lector. A este respecto, Sandro Cohen declara que "en $A s$ de oros el poeta recurre a una plétora de fuentes que podrían considerarse rebuscadas, aquí sobre todo clásicas y bíblicas". Para Cohen, "esto, incluso, podría obligar al lector a recurrir a un libro de consulta para comprender mejor alguno de los poemas" (2006). ${ }^{8}$ A pesar de esta complejidad declarada, indagaré los significados que anidan

6. Así piensa, por ejemplo, Miguel Ángel Múńoz cuando declara que "tras la imaginación constante y la intimidad $D e$ otro modo lo mismo (FCE, 1979), su anterior antología, surge la pasión y el amor como un momento en el que confluyen plenitud vital y la conciencia de la muerte". En muchos poemas, prosigue Múńoz, reconocemos las "palabras de un hombre de más de ochenta ańos". De ahí estas "voces lejanas, piedras arrojadas al viento, al agua y, a la vez, lápidas sentenciosas, que avisan de que lo que un día fue certeza hoy es nostalgia" (2014: 18-19). En este mismo sentido, no sorprende que un libro como Calacas, publicado en 2003 tenga como tema principal la muerte.

7. Para Alfredo Rosas Martínez, por ejemplo, "la poesía de Rubén Bonifaz Nuño está en íntima relación con los saberes heterodoxos que constituyen el ocultismo: la alquimia y la filosofía hermética son dos de ellos". Para Rosas Martínez, dentro de este ciclo creativo, el poemario As de oros (1981) participa del esfuerzo por alcanzar la "Obra en rojo o Rubedo"; por su parte, los poemarios Fuego de pobres y Siete de espadas corresponden a "la Obra en Negro o Nigredo, mientras que La flama en el espejo equivale esotéricamente a la Obra en Blanco o Albedo (2014: 53).

8. Por su parte, Carlos Gómez Carro ha señalado el interés del poeta por el azar, perceptible no sólo en el título que nos 
bajo la recurrencia del elemento especular en este poemario. Como ocurre con la casi totalidad de las composiciones de Bonifaz Nuño, los textos de As de oros no llevan títulos sino números. ${ }^{9}$ Esta precisión merece la pena para que se entienda por qué, a lo largo de este ensayo, la referencia a los poemas se hace habitualmente mediante números y no con títulos como de ordinario.

La fecunda corriente existencial que recorre la poesía de Rubén Bonifaz Nuño presenta como afluente insoslayable la meditación sobre el cuerpo. La envoltura física bajo la que todo ser humano aparece es el tema de muchas composiciones de As de oros. El sexto poema del libro, probablemente uno de los más dolorosos de la colección, expresa la intensa melancolía del hablante lírico ante su reflejo en el cristal. En el siguiente fragmento, la languidez del personaje poemático se construye a partir de un contraste significativo de tiempos verbales: el pasado, desde el que brotan reminiscencias de "hostiles rostros" y "deseos" incumplidos y el presente en el que apenas subsiste "la pesadumbre / del párpado alzado":

\author{
Del azogue ansioso, espejo adentro, \\ donde hostiles rostros me acecharon; \\ donde me dolieron los deseos \\ que no se cumplieron nunca, queda \\ tan sólo ya la pesadumbre \\ del párpado alzado, en una casa \\ desde hace siglos derrumbada.
}

(As de oros, 44)

Brota aquí en el primer verso la imagen del "azogue" como sinécdoque predilecta del espejo. La prosopopeya "azogue ansioso" tiene que interpretarse aquí como "azogue" que causa ansiedad en el yo lírico, y no como "azogue" que padece ansiedad en sí mismo. Es, en efecto, el enfrentamiento del sujeto textual con el espejo lo que le causa inquietud. Esta última se infiere también de la imagen del "párpado alzado" que apunta quizá una expresión facial de sorpresa ante la imagen transmitida por el espejo. El sintagma "espejo adentro" plantea la existencia de un espejo como espacio autónomo y profundo, contrastable con la realidad exterior en la que se ubica el sujeto poético. Se abren asimismo dos posibles interpretaciones. En primer lugar, "espejo adentro" puede corresponder a la ilusión física de la hondura del espejo, es decir que el cristal le brinda al observador una espacialidad hija de la proyección ilusoria de la tridimensionalidad del espacio real. ${ }^{10}$ En segundo lugar, se

interesa - As de oros — , sino también en otro como Siete de espadas (1966). En estos casos, la existencia se aparenta a un juego de cartas donde "soñamos con el as de oros" mientras nos acecha "con su augurio maléfico el siete de espadas". Lo único que nos queda es, entonces, "ceńirnos a la suerte" y en eso consiste precisamente la "baraja" de la vida (2007: 6).

9. Habría que interrogarse quizá sobre este repudio sistemático de rótulos en los textos del poeta veracruzano — salvo contadísimos casos - que desnuda el texto de toda nota de referencialidad. Al optar por los números, y no por títulos léxicos, el poeta aspira quizá a una mayor libertad de interpretación de sus composiciones o prefiere que la serie numerada ascendente de los poemas se lea como un conjunto solidario respecto al libro en el que aparecen.

10. Gaston Bachelard ha deplorado precisamente, en su ya citado ensayo, esta falta de profundidad del espejo artificial, en comparación con el espejo natural de las aguas. Para el filósofo, "los espejos son objetos demasiado civilizados, demasiado manejables, demasiado geométricos; son, con demasiada evidencia, instrumentos del sueño como para adaptarse por sí solos a la vida onírica". En cambio, el espejo de las aguas brinda "la oportunidad de una imaginación abierta", ya que, según Bachelard, las honduras del agua le ofrecen a Narciso una imagen inestable de sí mismo, imperfecta en las irregularidades del agua corriente y, por tanto, abierta a la perfectibilidad y al sueńo de un ideal aún por alcanzar. Por el contrario, "los espejos de cristal, en la viva luz de la habitación, dan una imagen demasiado estable" (2003: 40). 
puede entender como una metáfora de la memoria. En este segundo caso, "espejo adentro" puede significar "espejo interior de la memoria”. Desde esta segunda perspectiva, no hay un protagonismo aislado del espejo, sino un enfrentamiento del yo con sus transformaciones históricas cuyo lugar de comprobación es el espejo. Puesto que tales alteraciones no son procesos simultáneos sino progresivos y sucesivos, se puede concluir que la aparente simultaneidad entre el yo antiguo y el yo actual equivale más bien aquí a un efecto de la memoria. Ella, en efecto, es la única capaz de asir en el mismo lapso de tiempo las sucesivas alteraciones de una apariencia en su devenir histórico. Como ya he anticipado, la "pesadumbre/ del párpado alzado" evocada en el quinto y sexto versos, describe la mueca del rostro que descubre con perplejidad ante un cristal su propia metamorfosis. Esta misma memoria es la que conduce a la amarga resignación que cierra el segundo poema, casi a modo de balance parcial de los días recorridos hasta ahí:

Y he cambiado. Sordo, encanecido,

una oficina soy, un sueldo;

veinte mil pesos en escombros

y un Volkswagen, y la nostalgia

de lo que no tuve, y el insomnio,

y cáscaras de años devaluados.

(As de oros, 36)

Cuando el yo lírico intuye que la mayor parte de su vida está por detrás y no por delante, no puede sustraerse a este determinismo de su memoria que en tales casos hace un recuento de lo que tuvo o tiene. El inventario de lo que le queda parece desafortunadamente lamentable: un cuerpo desgastado por el tiempo, "sordo, encanecido", la frivolidad de un "Volkswagen" —curiosa coincidencia de tono e imagen con un conocido poema de José Emilio Pacheco ${ }^{11}-$ y, finalmente, una existencia cuyo transcurso irreversible se intuye ahora como "cáscaras de años devaluados". Volvemos a encontrar esta memoria atroz en el poema 26 en el que la metáfora del "fondo" del espejo cumple una función mnemónica:
$\mathrm{Y}$ un rostro fugaz y adolescente
que fuimos - fondo de un espejo
feroz- se apresura y nos alcanza
vertiginosamente, y tiembla
de arrugas, manchado, encanecido.
(As de oros, 102)

\footnotetext{
11. En el poema "Conversación romana", de No me preguntes cómo pasa el tiempo, Pacheco duda de la perdurabilidad de los versos que resisten probablemente menos que un Volkswagen (2009: 91). Tanto en Pacheco como en Bonifaz Nuño, el "Volkswagen" funciona como elemento arquetípico de la sociedad de consumo en la que el hombre moderno está inmerso, para subrayar la precariedad de las cosas, eligiendo como símbolo de esta fragilidad un modelo de coche célebre precisamente por su longevidad. La única diferencia es que en el texto de Pacheco, esta imagen sólo permite enfatizar la fugacidad de la poesía, mientras que en el poema de Bonifaz Nuño, el "Volkswagen" sugiere un aprovechamiento de los bienes económicos que depara la modernidad, sin que tales artefactos, por más resistentes que parezcan, puedan redimirnos de nuestra transformación fatídica.
} 
La distancia entre este "rostro", que chispea desde las grietas de una adolescencia lejana y las "arrugas" de la vejez actual, cristaliza en el "fondo de un espejo/ feroz". Es útil advertir de paso el encabalgamiento sirremático abrupto, que echa al verso siguiente el adjetivo "feroz", dando así una mayor relevancia a la ferocidad o violencia del "espejo". Esta ferocidad debe entenderse aquí como la radical juventud que, al compararse con la vejez, produce una intolerable amargura en el sujeto lírico. Tanto en este poema como en el anterior, la memoria del rostro joven resulta irreconciliable con la del rostro decrépito. La fugacidad del "rostro" lozano desbarata la ilusión de mocedad perenne, haciendo de ella un verdadero espejismo en el doble sentido de la palabra: es una imagen que sólo vive en la "memoria" del espejo, pero también es una alucinación del hombre adulto que se rehúsa a admitir su verdadera fisonomía hecha de "arrugas", manchas y canas. Al mirarse ante el espejo, se espera que el sujeto establezca una coincidencia con el reflejo que le devuelve el cristal. No ocurre esta identificación en el sexto poema de As de oros al que me refería, sino todo lo contrario. La nostalgia ante las mutaciones del cuerpo revela, entonces, al menos en apariencia, una incapacidad por parte del yo lírico de hallar la continuidad biológica de su ser, por encima de sus mutaciones históricas, acto de adaptación tan esencial a la construcción psicológica de la identidad. ${ }^{12}$ De ahí la escisión del yo y su repudio: "alguien que no soy yo se burla/ enfrente de mí, que lo descubro" (44). Para Carlos Gómez Carro, en estos casos, el hablante lírico de Bonifaz Nuño es "el viejo que en el espejo se mira encanecido y mira también, desde quien fue, lo que quiso ser, armado de valor, a pesar de todo" (2007: 8).

En uno de sus cuentos, Borges ha deplorado la incidencia nefasta de los espejos y la cópula sobre la demografía. ${ }^{13}$ Semejante afirmación resulta fascinante, no sólo por su humor, sino también por su lógica borgeana en la cual adquieren existencia tangible entidades que parecían confinadas a la virtualidad de las imágenes especulares. Es sin embargo la idea que se repite en el poema de Bonifaz Nuńo cuando el hablante lírico niega ser ontológicamente idéntico al que lo escruta del otro lado del espejo. Quisiera explayarme sobre este desdoblamiento como una de las facetas de la poética especular del poeta veracruzano.

\section{El tema del doble como crisis especular de la identidad}

En rigor, la conciencia de la finitud no se le revela al ser ante el espejo, sino que se vuelve más concreta, más apremiante y comprobable que de ordinario, cuando las huellas físicas de la vejez instan al sujeto contemplador a recordar melancólicamente el rostro prístino que fue suyo. De este juego entre la amarga verdad del presente y la reminiscencia del pasado nace, a mi entender, el proceso del desdoblamiento especular. En el mismo sexto poema que vengo comentando, la

12. Quien mejor lo explica es Edmond Marc con los siguientes términos: “L'identité corporelle doit s'adapter à l'évolution biologique et sociale avec ses moments clés comme la puberté, la maternité, la maturité, le vieillissement; chacun de ces moments pousse à un remaniement de l'identité corporelle qui retentit sur le sentiment global d'identité (2005: 45-46). (La identidad corporal debe adaptarse a la evolución biológica y social, con sus momentos clave tales como la pubertad, la maternidad, la madurez, el envejecimiento; cada uno de estos momentos empuja a una remodelación de la identidad corporal que repercute en el sentimiento global de identidad) (traducción mía).

13. Me refiero por supuesto al relato "Tlön, Uqbar, Orbis Tertius" de Ficciones donde leemos lo siguiente: "Descubrimos (en la alta noche ese descubrimiento es inevitable) que los espejos tienen algo monstruoso. Entonces Bioy Casares recordó que uno de los heresiarcas de Uqbar había declarado que los espejos y la cópula son abominables, porque multiplican el número de los hombres" (1984: 431). 
duplicidad como tema de la memoria se materializa por la referencia a este enigmático "huésped rojizo" alojado en el propio yo, "bajo el palio/ de la ceniza" (44). La metáfora "palio de la ceniza" es una referencia a la precariedad del cuerpo, escindido inexorablemente entre "lo que fui" y "la ruina en que me sobrevivo" (44). Desde el punto de vista morfosintáctico, los tiempos verbales de estos últimos versos contrastan al ser antiguo - "lo que fui" — con los vestigios desintegrados del ser actual — "la ruina en que me sobrevivo"- La constatación de la transformación física es una calamidad para quien se contempla y resigna ante "la imagen/ que me atosiga, vencedora" (44).

El espejo deja, pues, de reflejar a quien se mira hic et nunc en él para blandir algo distinto, un ser que ya se transformó, pero que la memoria del espejo atesora como algo intacto, incorrupto e incluso incorruptible. ¿Cómo entender de otro modo el siguiente remate del poema 9: "alguien que fui me está mirando/ y mirándolo estoy, y miro/ en el que fui que soy" (52)? Con todo, postular, como acabo de hacer, una memoria del espejo equivale menos a humanizar al objeto-cristal que a aludir a un proceso de traslación que se opera en el propio individuo. Esto significa que al mirarse, el sujeto es quien recuerda su antigua apariencia y ésta parece emerger del pasado y colocarse irónica o burlonamente del otro lado del vidrio junto a la figura actual. Se puede decir, pues, que en Bonifaz Nuño, el acto de contemplación ante el espejo transmuta la desagradable actualidad física del yo con la utópica perpetuidad de la lozanía supuestamente intacta. Esto me permite advertir la facilidad con la que el motivo del doble ha sido reducido a menudo en la crítica de Rubén Bonifaz Nuño. De hecho, se ha señalado en la obra del poeta veracruzano la preocupación constante por presencias enigmáticas que cohabitan con el hombre, especies de alter egos que acompañan al sujeto poético de Bonifaz Nuño. Si esto es válido en varios textos, es preciso cuidarnos, sin embargo, de generalizaciones demasiado rápidas. Sandro Cohen evoca, por ejemplo, misteriosas presencias en varios textos de nuestro autor y las relaciona incluso con la dicotomía humana del bien y del mal o con el tema del libre albedrío (2006). Entre la variedad de ejemplos que el crítico convoca para ilustrar sus ideas, figura un fragmento del sexto poema de As de oros sobre el que ya me he explayado lo suficiente. Me consta personalmente que este poema no encaja demasiado con el propósito de Cohen porque la alteridad que parece escudriñar al yo en esta composición es menos una entidad misteriosa que cohabita en el hombre que un resultado del desdén por la propia apariencia degradada como ya queda dicho. El sujeto poemático se desdobla porque separa su apariencia joven del rostro marchito del presente. La ruptura se debe a la profundidad de las mutaciones ocurridas y a la certeza de la irreversibilidad de las mismas. No se trata, por tanto, de una presencia extraña, sino de un juego de la memoria.

Este "alguien que no soy yo" (44) demuestra, pues, que juventud y senectud son etapas intuidas como dos épocas irreconciliables del mismo ser. Hay por tanto un yo joven que, desde el baluarte de la memoria, escruta al rostro marchito del álter ego actual, contemporáneo y verídico, a la vez que es escrutado por éste, creándose así una duplicidad dolorosa nutrida por la melancolía. El proceso de la reflexión especular se complica, entonces, al involucrar ahora no sólo al objeto "espejo", sino también a la memoria y las miradas cruzadas de las dos entidades en presencia. Los ojos del sujeto real atraviesan los del sujeto virtual especular y viceversa. Esta especularidad alternativa conseguida por los ojos no es nada novedosa como explica Edmond Marc: "le miroir n'est pas seul à refléter des images; sans cesse nous sommes confrontés aux images qui nous sont renvoyées par le regard d'autrui et avec lesquelles nous avons à faire coïncider l'expérience intérieure que nous avons de 
nous-mêmes" (2005 : 45). ${ }^{14}$ La mirada triunfante es aquí, con todo, la del reflejo que se burla del ser real. Las últimas estrofas de la composición acentúan el conflicto entre el yo y su reflejo:

Desde sus canas, desteñido;

desde sus arrugas — cárcel— preso;

desde su gordura floja, atado,

alguien que no soy yo se burla

enfrente de mí, que lo descubro.

(As de oros, 44)

La meditación acerca del cuerpo se construye aquí sobre la oposición entre juventud y senectud, lo cual representa una de las obsesiones literarias de Rubén Bonifaz Nuño. No resulta sorprendente, por consiguiente, que en determinados casos, el motivo del cuerpo vertebre el conjunto de un volumen lírico. ${ }^{15}$ En el poema que acabo de reproducir, este contraste se construye sobre la pareja sujeto físico/ sujeto virtual especular. La certeza de la diferencia ontológica entre las dos entidades se transparenta en la negación rotunda de "alguien que no soy yo", lo que puede interpretarse como una conciencia de la imposibilidad de recuperar la apariencia perdida. La "burla" que se menciona explícitamente en el penúltimo verso demuestra que el deterioro es algo ineluctable. La escisión del yo se aprecia, desde el punto de vista enunciativo, en el contraste entre los determinantes posesivos que apuntan al otro yo y los determinantes personales que se refieren al ego que el poema nos blande como legítimo. Así, las figuraciones de la vejez — "Sus canas", "sus arrugas", "su gordura floja”apuntan al yo degradado que el hablante lírico intuye como un simple impostor. Lo verdaderamente dramático en esta aparente distorsión pesadillesca de la apariencia no es que realmente haya dos egos ontológicamente distintos, sino que tal conflicto no exprese más que la tragedia existencial de un mismo ser como ya he señalado. Desde esta perspectiva, las "canas", las "arrugas" o la "gordura floja" son atributos del mismo ser: éste que se rehúsa a enfrentar las mutaciones de su cuerpo y que finge hipócrita o irónicamente burlarse de otro que es él mismo. En este sentido, la afirmación del cuarto verso - "alguien que no soy yo..." - no se debe interpretar sin su insoslayable contenido melancólico. El poeta quisiera mucho que el reflejo demacrado que le devuelve el espejo no fuese suyo. Este deseo se repite en la última estrofa del poema - "Y el desprestigio que me mira/ como si yo fuera quien me miro" (45)—, reforzando la ilusión de separación ontológica entre el yo supuestamente postizo y el que se nos presenta como auténtico. El resto de la composición nos mantiene en esta conciencia de la duplicidad amarga:

Erosionado, desvalido,

por un nombre ajeno convocado,

14. El espejo no es único en reflejar imágenes; estamos continuamente confrontados a las imágenes que nos transmite la mirada ajena y con las que tenemos que hacer coincidir la experiencia interior que tenemos de nosotros mismos) (traducción mía).

15. No pienso sólo en un libro de título harto sugerente como Del templo de su cuerpo (1992), con composiciones arquetípicas como el poema "H" (1994: 246-247), sino también en poemarios como Pulsera para Lucía Méndez (1989) o Calacas (2003), librito, este último, que poetiza con resignación, ironía y amargura la conciencia de la finitud y la constante amenaza de la muerte. 
me vuelvo hacia mí; la siempre en vano

prometida flama me disuelve.

Y el desprestigio que me mira

como si yo fuera quien me miro,

crece de mi derrumbe, alienta

de opaca asfixia, se complace.

Y lo miro también, y asiste

mi condenación a su caída.

(As de oros, 45)

La primera estrofa resulta semánticamente oscura, no sólo por la confusión perceptible al nivel enunciativo - "me vuelvo hacia mí..." - sino también por la complejidad sintáctica de construcciones como "la siempre en vano/ prometida flama me disuelve". Se difuminan progresivamente las fronteras entre el sujeto activo y empírico, es decir, aquel que se coloca ante el cristal y el sujeto pasivo y virtual del espejo. El poema juega a confundir las dos entidades en una coalescencia que recuerda el "mirándome mirándose mirarme mirado" del poema “¿No hay salida?" de La estación violenta de Octavio Paz (1989: 78). Al final, ya no se sabe realmente quién mira y quién es mirado. La última estrofa se abre con una referencia a la mirada de "desprestigio" del alter ego virtual (1er verso), a la cual responde el yo en los dos últimos versos. Cada entidad se enfrenta a su propia desgracia; así, el yo tiene que asumir su "condenación” y el reflejo su "caída". Con todo, junto al lado oscuro de los espejos, junto a este azogue lacerante que he analizado hasta aquí, surgen igualmente en los poemas de Bonifaz Nuño reverberaciones de sosiego y consuelo producidas por la imaginería especular. En algunos casos, el espejo desempeña una función positiva al preservar el rostro de las metamorfosis nefastas descritas en las páginas anteriores.

\section{Espejo y teoría del instante}

Al reflejar al ser que se le coloca delante, el espejo no aprisiona sólo una porción de espacio, sino también de tiempo. El tiempo real en el que está inmerso el hombre que se contempla atraviesa el vidrio y, una vez del otro lado, se sustrae al determinismo de la sucesión de las horas para devenir en instante puro. Deja de resultar sorprendente la relación que aquí establezco entre el tema metafísico del instante y el motivo del espejo en Rubén Bonifaz Nuño si recordamos los siguientes versos del cuarto poema de As de oros: "y nada está sino el instante/ que va a caer, que habrá caído/ en un instante más; ahora/ nada más que espejo despoblado" (38). Si determinados rostros se conservan intactos en el espejo, parece sugerir el poeta, es porque en ellos ya no actúa el tiempo. Un caso interesante es la tercera composición de As de oros. En ella, el hablante lírico presenta al espejo como un lugar de reencuentro con los seres queridos del pasado cuya apariencia no ha sufrido los estragos del tiempo:

Año por año, cada día, en este espejo se miraron los que amé; como la flor naciente que habla del invierno, aquí frenaron 
su destrucción, o como llamas

que lo que consumen eternizan,

y salvaron la almendra ardiente

de donde sube la alegría.

(As de oros, 37$)^{16}$

En esta primera estrofa, el desfile de personajes ante el espejo está descrito como un proceso diario y existencial. El protagonismo del espejo está subrayado por el deíctico "este" en el segundo verso que lo actualiza, no sólo ante el hablante lírico, sino también ante el lector. Al decir "este espejo", el poeta arraiga su discurso en una experiencia concreta. Este proceso se prolonga a lo largo de la estrofa y en el resto del poema. Una de las funciones del espejo aparece explícitamente en estos primeros versos de la composición: si el cristal no es propiamente un baluarte contra la voracidad del devenir, llega a ser al menos un freno a la "destrucción", como afirman el cuarto y quinto versos. La segunda y la tercera estrofas, por su parte, encierran una idea sorprendente: los rostros de los que se miraron otrora en el espejo siguen presentes, extrañamente cuajados en "las galerías / ciegas del azogue":
Y están allí; recorren todos, sin hablarse entre sí, perdidos de tanta extensión, las galerías ciegas del azogue carcomido; allí se encuentran, se alzan claros de juventud incorruptible.
O se asoman a mirar, perfectos; sólo fantasmas que desprecian su cuerpo desplomado, y ponen otra vez en orden la sonrisa, edifican la imagen pura que no necesita la mirada de nadie, que sola se comprueba.
(As de oros, 37)

Interviene otra vez en este fragmento la ya referida sinécdoque predilecta del espejo: el "azogue". Sin esta superficie de mercurio que cubre el revés o fondo del espejo, la reflexión sería imposible. Se trata en este caso de una imagen ágil que apunta al fenómeno de la reflexión especular, prescindiendo del significante habitual "espejo". En las dos estrofas, la persistencia de los rostros del pasado es un recurso que atribuye al espejo facultades mnemónicas. Hay otro detalle importante que proporciona el poema de Bonifaz Nuño: el "azogue" no es intacto sino "carcomido", probablemente por el uso a lo largo de los ańos. Se puede decir, por tanto, que la vetustez del cristal no es un detalle casual sino que apunta al paso del tiempo, otro eje vertebral de la poética de Bonifaz Nuńo. Resulta lógico, pues, que en la última estrofa citada, el discurso lírico se haga portador de la tensión entre la degradación del cuerpo en el tiempo y su conservación intacta en lo que podríamos llamar memoria

16. Las citas de corpus proceden del volumen Versos (1978-1994), México: Fondo de Cultura Económica, 1996. 
del espejo. Quienes "se asoman a mirar, perfectos" son sin duda sombras, "fantasmas" que no se resignan a tener ese "cuerpo desplomado" y que prefieren aferrarse a una "imagen pura", intocada, de sí mismos.

Algo similar ocurre en el poema 21 (86-87). En esta composición, la fugacidad se abole momentáneamente en "las escalas sin término de la música" y en "las repeticiones infinitas/ de un espejo en ondas perezosas". Tenemos la impresión de vivir uno de estos instantes epifánicos que recuerdan a un poeta como Octavio Paz, momentos en los que la sucesión desenfrenada de acontecimientos cede lugar a un tiempo eufórico que lo transforma todo en presencia instantánea. Los acontecimientos, los objetos y las imágenes se momifican en la superficie de vidrio:

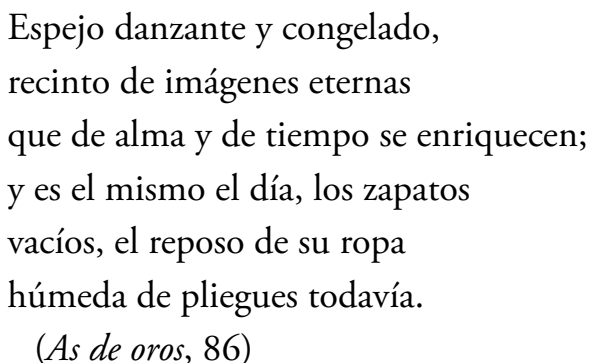

El adjetivo "congelado" empleado en el primer verso en referencia al "espejo" sugiere la idea del cristal como una forma de agua cuajada. El segundo verso - "recinto de imágenes eternas"esclarece la imagen del "espejo danzante y congelado" al apuntar esta vez, ya no a su forma material, sino a su función simbólica: el espejo perenniza las "imágenes en la medida en que es una metáfora de la memoria que triunfa del olvido.

\section{Conclusiones}

Este recorrido somero de las figuraciones del espejo y de lo especular en As de oros de Rubén Bonifaz Nuño ha permitido analizar las redes de significaciones que se abren ante estos motivos a lo largo del poemario. Hemos retenido en esta reflexión tres perspectivas del espejo. La primera apunta a la revelación de las mutaciones que ocurren en la apariencia física del individuo. En la segunda, el poeta plantea la existencia de un doble especular que he interpretado como la idealización del rostro joven en su confrontación dolorosa con la apariencia degradada. Por último, como tercera perspectiva del espejo, he mostrado en qué medida éste funciona como una metáfora del instante puro. En este caso, la imagen que se refleja en el espejo se sustrae a la voracidad del devenir. El reflejo del ser se conserva, entonces, inalterable en el cristal, como si existiera del otro lado del espejo una fuente de perenne juventud. Tales aspectos confieren a la poética de Bonifaz Nuño un profundo sello existencial. Lo especular no constituye, por tanto, un rasgo aislable del conjunto de la poética del autor, sino que mantiene una estrecha relación con las preocupaciones predilectas del poeta, muchas de las cuales hilvanan su escritura con la lírica precortesiana. Hay, por ejemplo, una composición de As de oros —el poema 17- en la que resuenan con ecos inquietantes las palabras del rey-poeta de Texcoco, Nezahualcóyotl: "Todo es aquí prestado; causa de burla, / todo lo que hacemos; / sólo, aquí, fantasmas nuestra siembra" (74). Puesto que estamos condenados a perder el rostro literalmente, es decir, a reconfigurar constantemente la imagen que tenemos de nosotros mismos a medida que se modifica nuestra fisonomía, el poeta nos invita a reconciliarnos con esta 
herencia escurridiza y deleznable de la carne, sabiduría obligada que se nos revela años tras años en la callada elocuencia de los espejos.

\section{Referencias bibliográficas}

BACHELARD, G. (2003). El agua y los sueños (traducción de Ida Vitale), México, Fondo de Cultura Económica.

BALLON AGUIRRE, E. (2015). "Prólogo" en César Vallejo, Obra poética completa, Caracas, Biblioteca Ayacucho, pp. IX-LXXVII.

BORGES, J. L. (1984). Obras completas 1923-1972, Buenos Aires, Emecé Editores.

CHEVAlIER, J., GHEERBRANT, A. (1990). Dictionnaire des symboles, Paris, Robert Laffont/ Jupiter.

COHEN, S. (2006). "A brazo partido en el lugar del canto", en Alforja 37 [en línea]: http://www. alforjapoesia.com/monografico/mon37.htm . (2008). "El fondo de la forma en la poesía de Rubén Bonifaz Nuño" en Tema y variaciones de literatura núm. 31, pp. 105-131, [en línea]: http://zaloamati.azc.uam.mx/handle/11191/2858

GÓMEZ CARRO, C. (2007).“El dulce sabor de la amargura. Poema y poesía en Rubén Bonifaz Nuño", en Casa del tiempo núms. 95-96, pp. 2-9: [en línea]: http://www.uam.mx/difusion/ casadeltiempo/95_96_dic_ene_2007/

HUIDOBRO, V. (2011). El espejo de agua, Bogotá, Editorial Linotipia Bolívar.

MARC, E. (2005). Psychologie de l'identité. Soi et le groupe, París, Dunod.

MONTEMAYOR, C. (2008). "Nota introductoria" en Rubén Bonifaz Nuño (Antología), México, Unam, pp. 4-5.

MÚÑOZ, M. Á. (2014). "Rubén Bonifaz Nuño: el juego de la memoria estética", en revista $E l$ Búho núm. 158, México, María del Rosario Casco Montoya, pp. 16-23.

NUÑO, R. B. (1996). Versos (1978-1994), México, Fondo de Cultura Económica.

PACHECO, J. E. (2010). Tarde o temprano (Poemas 1958-2009), Barcelona, Tusquets Editores.

PAZ, O. (1989). Lo mejor de Octavio Paz, Barcelona, Seix Barral. . (2008). Los hijos del limo, Santiago de Chile, Tajamar.

RIFFATERRE, M. (1983). Sémiotique de la poésie, Paris, Seuil.

ROSAS MARTÍNEZ, A. (2014). "As de oros es triunfo: la alquimia en la poesía de Rubén Bonifaz

Nuño", en Unidiversidad no 13, (Revista de pensamiento y cultura de la BUAP) (Benemérita Universidad Autónoma de Puebla), Puebla, Pernas y Cía.

VALLEJO, C. (2015). Obra poética completa, Caracas, Biblioteca Ayacucho.

VILLAURRUTIA, X. (2001). Nostalgia de la muerte, México, Fondo de Cultura Económica. 